\title{
Word-Blindness and Reading Comprehension Achievement of Students in Ogun State
}

\author{
B. Oluwakemi Adekola ${ }^{1 *}$, Olanrewaju A. Ibrahim ${ }^{2}$, Oluseun F. Lawal ${ }^{3}$ \\ ${ }^{I}$ Department of Arts and Social Sciences Education, Olabisi Onabanjo University, Ago-Iwoye, Ogun State, \\ Nigeria \\ ${ }^{2}$ Department of Educational Foundations and Counselling, Olabisi Onabanjo University, Ago-Iwoye, Ogun \\ State, Nigeria \\ 3Institute of Education, Olabisi Onabanjo University, Ago-Iwoye, Ogun State, Nigeria
}

*Corresponding Author: B. Oluwakemi Adekola, Department of Arts and Social Sciences Education, Olabisi Onabanjo University, Ago-Iwoye, Ogun State, Nigeria

\begin{abstract}
The study investigated the word-blindness and reading comprehension achievement of students in Ogun state Secondary Schools. This study adopted an ex-post facto design approach. The target groups for the study were Ogun State Senior Secondary School students in Nigeria. The samples were drawn from six (6) Local Government areas in Ogun State of Nigeria (Ijebu-Ode, Ijebu-North, Abeokuta North, Remo North, Ado-Odo/Ota and Ewekoro). Multi-stage random sampling technique was used to select five co-educational Public Secondary Schools from each of the six Local Government Area. Where fifty (50) Students were selected from each of the schools making a total number of three hundred (300) students from each of the schools in Ogun State of Nigeria. Two instruments, Reading Deficiency questionnaire which is a researcher based instruments and an achievement test in English Comprehension were used to collect data from the respondents. The instrument has two sections; Section A of the instrument focuses on demographic information of the Students while Section B of the instrument contains items eliciting information from the students on reading deficiency. The achievement test was based on reading comprehension. The validity and reliability of the instrument were determined by trial testing the instrument on the similar set of the sample in some other schools that were not part of sample population and the Kurder-Richardson 21 formula was used to obtain the inter-item reliability coefficient of 0.85 and 0.80 respectively. The data were subjected to Descriptive statistics, Pearson product moment correlation coefficient and t-test. Data were tested for significance at the 0.05 level. Based on the findings, it was detected that there is a significant relationship between reading deficiency and students' achievement. Part of the recommendations made was that teachers should help students develop strategies for building a good reading habit and proper understanding comprehension of language skills.
\end{abstract}

Keywords: Word-Blindness, Achievement, Reading, English Comprehension

\section{INTRODUCTION}

Reading has been defined from different perspective by different people. A layman definition of reading" is a communication process, through which information is transmitted from a writer to a reader by means of written symbols. Also, it means a way or an act of re-organizing understanding and interpreting the printed symbols or signs on any written materials.

Reading is "a highly complex activity including various important aspects such as recognizing symbols quickly and accurately, apprehending clearly with discrimination of the meaning implied by the author in harmony with the reader's purpose and interpreting them into definite thought and action patterns." From educational point of view as the focus of this research work, it can be deduced from above definition that "reading" is an act of mental development putting into action, some sense organs to recognize symbols, apprehends writer's intention interpreting them into definite thought for a better mental development and state of mind. Literary works and books of a general nature is one of the major sources of information for writing English Language, the pleasure derived from a good story, materials, and newspapers, etc. is in itself a reward for reading but the major aspect is that the more widely an individual reads, the more exposed and meaningful the information, conversation and discussion of such becomes, rich and more skillful. Reading is a communication process fundamental 
to any formal learning. It involves receiving message through a verbal mean of written code. The phenomenon involved in the communication process of reading is eclectic. Mabekoje (2005) defined reading as a communication process through which information is transmitted from a writer to a reader by means of written or printed words and the ability to understand the meaning of such symbols.

There are two forms of reading, namely: reading comprehension and reading for information. Reading comprehension as the name denotes means reading for proper understanding. It is a qualitative reading because it transcends mere reading information. Reading includes studying the title and bringing out his/her own ideal meaning. Put himself/herself in the position of the writer. Reading is the first step towards raising and independent learner.

Reading comprehension is the ability to read text, process it, and understand its meaning. (Tompkins, 2011) An individual's ability to comprehend text is influenced by their traits and skills, one of which is the ability to make inferences. If word recognition is difficult, students use too much of their processing capacity to read individual words, which interferes with their ability to comprehend what is read. There are numbers of approaches nto improve reading comprehension, including improving one's vocabulary and reading strategies (Cain \& Oakhill, 2009).

Reading comprehension is as the level of understanding of a text. This understanding comes from the interaction between the words that are written, and how they trigger knowledge outside the text. Comprehension is a "creative, multifaceted process" dependent upon four language skills: phonology, syntax, semantics, and pragmatics. Proficient reading depends on the ability to recognize words quickly and effortlessly. It is also determined by an individual's cognitive development, which is "the construction of thought processes". Some people learn through education or instruction and others through direct experiences (Adams, 1994)

Wilda (2005) carried out a research and survey which have shown that the percentage of the children in the public schools are seriously retarded in reading which started from the elementary school, therefore, since reading is language skill, proficiency in effective skill at the secondary level is very important to each student's future success in academic, social, economy and political career to attain a level of competence in reading.

There are specific traits that determine how successfully an individual will comprehend text, including prior knowledge about the subject, well-developed language, and the ability to make inferences. However, failure to do above leads to word-blindness in reading of any student or any individual.

Word-blindness is a specific learning disability that is neurological in origin. It is characterized by difficulties with accurate and/or fluent word recognition and by poor spelling and decoding abilities. These difficulties typically result from a deficit in the phonological component of language that is often unexpected in relation to other cognitive abilities and the provision of effective classroom instruction. Secondary consequences may include problems in reading comprehension and reduced reading experience that can impede the growth of vocabulary and background knowledge (Moats \& Dakin, 2008).

It is crucial to be able to recognize the signs of symptoms of word-blindness. The earlier a child is evaluated, the sooner he or she can obtain the appropriate instruction and accommodations he or she needs to succeed in school.

General problems experienced by people with word-blindness include the following:

- Learning to speak

- Learning letters and their sounds

- Organizing written and spoken language

- Memorizing number facts

- Reading quickly enough to comprehend

- Keeping up with and comprehending longer reading assignments

- Spelling

- Learning a foreign language 
- Correctly doing math operations

- Some specific signs for elementary aged children may include:

- Difficulty with remembering simple sequences such as counting to 20, naming the days of the week, or reciting the alphabet

- Difficulty understanding the rhyming of words, such as knowing that fat rhymes with cat Trouble recognizing words that begin with the same sound (for example, that bird, baby", and big all start with $b$ ) Pronunciation difficulties

Ajibola (2006) in his own view relate word-blindness to reading deficiency, he explains that reading deficiencies are the habit that we should guide against in students as identified by.

Head Movement: When a reader moves his or her head from side to side while reading.

Pointing to words: This happen when a reader follows the line with a finger or with a pen or a ruler, it is also called fingering.

Vocalization: This is when a reader who is reading for personal information or examination vocalizes words while reading. It is a deficiency except it is an oral drill during a broadcasting section, where it could be allowed.

Sub-Vocalization: This does not actually involve moving of the vocal organs but says the words to one self mentally. This is difficult to identify.

Regression: This deficiency refers to the backward movement of the eyes in order to re-read or look at words, phrases and sentences that have already been passed or read when there is lack of concentration.

Recognition Span: This refers to the number of words that the students can recognize each time, there is an eye fixation at a point, small recognition span is an evidence of poor reading.

Eyes Movement: This refers to the way the eyes moves across the line of the print during reading. An efficient reader moves his/her eyes across and down a page in a steady sweeping movement making as few regressions are absolutely necessary for understanding. Whereas a poor reader move his/her eyes across a line of print in a haphazard manner.

\section{Statement of the Problem}

An individual's ability to comprehend text is influenced by their traits and skills, one of which is the ability to make inferences. If word recognition is difficult, students use too much of their processing capacity to read individual words, which interferes with their ability to comprehend what is read. There are number of factors affecting reading comprehension, amongst these factors is wordblindness, this study assessed the impact of word-blindness on achievement of students in English comprehension;

\section{OBJECTIVES OF THE STUDY}

The main objective of this study is to assess word-blindness and reading comprehension achievement of students in Ogun state; it also assessed the impact of family background on word-blindness and gender on reading achievement of students.

\section{RESEARCH QueSTIONS}

The following research questions are formulated to guide this study;

- Is there is no significant relationship between word-blindness and students achievement?

- To what extent would the background contribute to the reading deficiency of students?

- To what extent would the gender affect the reading achievement of students?

\section{METHODS}

\subsection{Design}

The study employed the ex-post-facto research design, because the researcher is only interested in finding the fact that this research has to establish the effect of word-blindness and reading comprehension achievement of students, without necessarily manipulating it any form. 


\subsection{Participants}

The population of this study consisted of all senior secondary school students in Six Local Government Area of Ogun State: namely, -Ode, Ijebu-North, Abeokuta North, Remo North, AdoOdo/Ota and Ewekoro. Multi-stage random sampling techniques was employed in selecting the sample. Six Senior Secondary Schools are selected from each of the Local Government through random sampling technique, all the names of the schools in each of the zone were written in pieces of paper, squeezed, dropped and shuffle in a bowl and six (6) pieces of the paper was selected one after the other for each of the Local Government. Fifty (50) students was selected from each of the schools and stratified random sampling technique was employed in selecting 25 males and 25 females from each schools making a total number of three hundred (300) students from each of the selected six (6) Local Governments in Ogun State of Nigeria.

\subsection{Instruments}

The instruments used for this study are two instruments, a questionnaire and an achievement test on reading comprehension. Reading deficiency questionnaire is a researcher based questionnaire to elicit information on word-blindness and an achievement test in English Comprehension. The questionnaire has two sections; Section A of the instrument focuses on demographic information of the Students while Section B of the instrument contains items eliciting information from the students on wordblindness. The achievement test was based on reading comprehension. The validity and reliability of the questionnaire was determined by trial testing the instrument on the similar set of the sample in some other schools that were not part of sample population and the Kurder-Richardson 21 formula was used to obtain the inter-item reliability coefficient of 0.85 and items on achievement test on reading comprehension was extracted from a past questions of Ogun state unified examinations on English Language. This was used because it is a standardized questions set and vetted by qualified teaching personnel in Ogun State.

\subsection{Data Collection Procedure}

The instruments were administered in all the selected schools, after seeking necessary permissions from school authorities. All copies were retrieved. The researchers personally travelled to administer the instruments to the participants. Data collection lasted for two months.

\subsection{Data Analysis}

The data analysis involved correlation matrices and multiple regression Analysis. The results were tested at 0.05 level of significance.

\section{RESUlts}

Answers to Research Questions

\subsection{Research Questions One: Is there is No Significant Relationship between Word-Blindness and Students' Achievement?}

Table1. Relationship between word-blindness and students' achievement

\begin{tabular}{|l|l|l|l|l|l|l|}
\hline \multicolumn{1}{|c|}{ Variable } & \multicolumn{1}{|c|}{$\mathbf{N}$} & \multicolumn{1}{c|}{ Mean } & \multicolumn{1}{c|}{ STD } & R & P & Remark \\
\hline Students achievement & 300 & 52.64 & 3.24 & & & \\
\cline { 1 - 4 } Reading deficiency & 300 & 32.19 & 2.65 & $0.584^{* *}$ & $<0.05$ & Significant \\
\hline
\end{tabular}

Note: ** Implies significant at 0.01 level (i.e. $99 \%$ confidence level)

The table above presents correlation analysis showing significant relationship between wordblindness and students' achievement. The result of the descriptive analysis presented above shows that the mean score for students' achievement is52.64 while that of word-blindness is 32.19 with standard deviation of 3.24 and 2.65 respectively. The mean differences were significant at 0.01 level of significance. Thus, there is a significant relationship between word-blindness and students' achievement. Nevertheless, the correlation value of 0.584 whose probability close to zero percent shows statically that at 0.01 level of significant, there is a statistical evidence to conclude that wordblindness affects students. Therefore, there is a significant relationship between word-blindness and students' achievement. 
This corroborate with the finding of Ayo, Banjo and Bison (2006) that depicted that students with mental retardation are slower on language development, show a depressed rate on developing vocabulary and have a lower final level of language development. Ideal (2009) also affirmed that the brighter the student, the better they read.

\subsection{Research Question Two: To what Extent would the Background Contribute to the Word- Blindness of Students?}

Table2. Impact of family background on word-blindness

\begin{tabular}{|c|c|c|c|c|}
\hline $\begin{array}{l}\mathbf{R}^{2} \\
\text { Adjusted } \mathbf{R}^{2} \\
\text { F-Statistic }\end{array}$ & $\begin{array}{l}0.250 \\
0.165 \\
26.212 \\
\end{array}$ & & & \\
\hline Parameter & \begin{tabular}{l|l} 
& Coefficient \\
\end{tabular} & Standard Error & T-cal & Probability \\
\hline Constant & 23.167 & 1.34 & 19.15 & 0.000 \\
\hline Background & 0.412 & 0.05 & 5.04 & 0.000 \\
\hline
\end{tabular}

In the table above, family background as the only independent Variable accounts for about $41 \%$ of the total variation in word-blindness $\left(\mathrm{R}^{2}=0.250, \mathrm{P}<0.05\right)$. This is significant. Therefore, backgrounds play a significant role on word-blindness of secondary school students. This goes in line with the research conducted by the NERDC (2013), the relative contribution of the two factors, family and twins to a deficit in reading have been assessed in reader with normal range intelligence (above go on verbal or achievement IQ)and apparent educational opportunity (their first language is English and they regularly attended school that were at or above national norms in reading).with all said by the professional, it could be deduced that reading deficiency could be inherited from parents.

\subsection{Research Question Three: To what Extent would the Gender Affect the Reading Achievement of Students?}

Table3. Gender on reading achievement of students

\begin{tabular}{|l|c|l|l|l|l|l|}
\hline \multicolumn{1}{|c|}{ Gender } & N & \multicolumn{1}{|c|}{ Mean } & STD & t-cal & \multicolumn{1}{c|}{ P } & Remark \\
\hline Male & 150 & 36.12 & 2.53 & & & not significant \\
\hline Female & 150 & 31.16 & 2.51 & 0.22 & $>0.05$ & \\
\hline
\end{tabular}

In table 3 above, there is no significant differences ( $\mathrm{tcal}=0.22, \mathrm{P}>0.05$ ). This is not significant. Therefore, reading achievement of students is not sensitive to gender. Therefore there is no significant gender difference in reading achievement of students.

\section{CONCLUSION}

Conclusively, there is a significant relationship between reading deficiency and students' achievement. Family background plays a significant role on reading deficiency of secondary school students. There is no significant gender difference in reading achievement of students.

Word-blindness is not a disease but rather a fault, meaning some habit people exhibit freely without conscious effort such habit as it becomes part and parcel of such person and the lower the achievement of such person becomes in understanding and speed.

There are levels in education. Therefore, it is not easy to change student who displays such deficiency in reading because it might affect the academic achievement. Therefore, in no way should teachers allow student pick any habit while reading because it is comfortable but rather learning the proper way and habit of reading.

\section{RECOMMENDATIONS}

In view of what this research work has examined, the data collected and the rate at which wordblindness is spreading in various school in this country, the following recommendation are here by stated.

$>$ Seminars and workshop should be organized to look specifically in to the aspect of reading and reading deficiencies in-service training for teachers.

$>$ Teachers should help students to develop strategies for building a good reading habit and proper understanding of language system. This will widen the teachers' horizon on how to handle students with reading deficiencies and how they can help learn a good habit and skills. 
Since the ability of students who manifest word-blindness is low, the reading habit should be monitored corrected within the elementary to the secondary, because when it becomes a habit, it will not be easy to change at the Tertiary level.

\section{REFERENCES}

[1] Adams, Marilyn McCord (1994). Beginning to read: thinking and learning about print. Cambridge,Mass: MIT Press. ISBN 0-262-51076-6. OCLC 62108874.

[2] Ajibola, A.(2006).A practical guide to purposeful reading for students, School Panorama.

[3] Akinbode, J.O.(2006). Reason for ass failure in secondary certificate. Casell publishing company London.

[4] Ayo,Banjo and Bison J.O. (2006). Developmental English, Spectrum Books Limited, Ibadan Nigeria.

[5] Bond, G.L \& Tinker, M.(1973). Reading difficulties: their diagnosis and correction, Englewood cliffs, N. J. Pretice Hall.

[6] Cain, K., Oakhill, J. (2009). "The Behavioral and Biological Foundations of Reading Comprehension". Guilford Press: 143-175.

[7] Cerritors College(2003). Reading skills tutorials; counseling and developmental center, reading skills for university, Ontario, Canada, York University.

[8] Ideal (2009). Institution for the Developmental of Educational Achievement.

[9] Imiewain, Alleburu (2002). Basic Principles of English, Immaculate city Publishers, Oyo State, Nigeria.

[10] Mabekoje, O. (2005). Understanding English grammar; Art of communication. lucky Odoni (Nigeria) Enterprises, Ijebu-Ode, Ogun State.

[11] Moats, L. C. \& Dakin, K. (2008). Basic facts about Dyslexia and other Reading Problems. Baltimore, MD: International Dyslexia Association.

[12] Omolewa, M.(2001). The challenge of education in Nigeria, Ibadan, University Press.

[13] Tompkins, G.E. (2011). Literacy in the early grades: A successful start for prek-4 readers (3rd edition), Boston, Pearson. pp. 205, 208-209, 211-212.

[14] Unoh, S. (1986). The study of reading, Ibadan University Press. Website: www.google.com.

\section{AUTHOR's BIOGRAPHY}

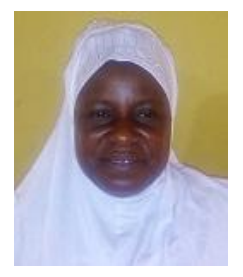

Dr Busurat Oluwakemi Adekola is an Associate professor at department of arts and social sciences education, faculty of education, olabisi Onabanjo University, agoiwoye. She specialized in language education.

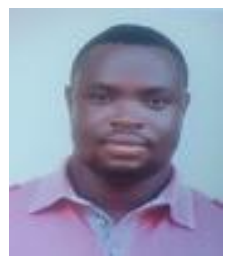

Mr. Lawal Oluseun Fatai is a research assistant at the institute of education, faculty of education, olabisi Onabanjo University, ago-iwoye. He specialised in language education.

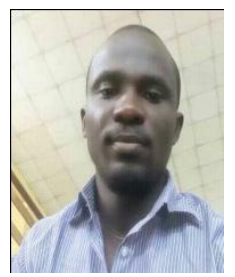

Mr.Ibrahim Olanrewaju Abiodun is a doctoral student at the department of educational foundation and counseling.

Citation: B. Oluwakemi Adekola, Olanrewaju A. Ibrahim, Oluseun F. Lawal. "Word-Blindness and Reading Comprehension Achievement of Students in Ogun State" International Journal on Studies in English Language and Literature (IJSELL), vol 6, no. 5, 2018, pp. 31-36. doi:http://dx.doi.org/10.20431/2347-3134.0605005.

Copyright: () 2018 Authors. This is an open-access article distributed under the terms of the Creative Commons Attribution License, which permits unrestricted use, distribution, and reproduction in any medium, provided the original author and source are credited. 